Canadian University Music Review

Revue de musique des universités canadiennes

\title{
An Interview with György Ligeti in Hamburg
}

\section{Stephen Satory}

Volume 10, numéro 1, 1990

URI : https://id.erudit.org/iderudit/1014897ar

DOI : https://doi.org/10.7202/1014897ar

Aller au sommaire du numéro

\section{Éditeur(s)}

Canadian University Music Society / Société de musique des universités

canadiennes

\section{ISSN}

0710-0353 (imprimé)

2291-2436 (numérique)

Découvrir la revue

\section{Citer ce document}

Satory, S. (1990). An Interview with György Ligeti in Hamburg. Canadian

University Music Review / Revue de musique des universités canadiennes, 10(1),

101-117. https://doi.org/10.7202/1014897ar

All Rights Reserved (C Canadian University Music Society / Société de musique des universités canadiennes, 1990
Ce document est protégé par la loi sur le droit d'auteur. L’utilisation des services d’Érudit (y compris la reproduction) est assujettie à sa politique d'utilisation que vous pouvez consulter en ligne.

https://apropos.erudit.org/fr/usagers/politique-dutilisation/ 


\title{
COLLOQUY
}

\section{AN INTERVIEW WITH GYÖRGY LIGETI IN HAMBURG}

\author{
Stephen Satory
}

In gathering information for my doctoral dissertation on contemporary string quartet composition in Hungary, I conducted interviews with twenty composers in Budapest. In the course of these interviews, several composers maintained that their composition has been influenced substantially by the music of György Ligeti, in particular by Ligeti's "micropolyphonic" style.

It became clear, therefore, that in order to account fully for the style of contemporary Hungarian string quartet composition, it was necessary for me to study the music of Ligeti, particularly his Second String Quartet, a work well known to Hungarian composers. ${ }^{2}$ In interviewing Ligeti I hoped to record his perceptions about this work. I hoped also to have him discuss the diverse influences to which he has been exposed in the West, influences which have affected composers living in Hungary to a much lesser extent until recently.

After many exchanges of correspondence with Mr. Ligeti's secretary, Dr. Louise Duchesneau, I succeeded in securing a date to meet Mr. Ligeti at his apartment in Hamburg on 9 June 1988. I arrived on the previous day and managed to contact Dr. Duchesneau by telephone. She invited me at once to

1 Ligeti described "micropolyphony" in the following manner: "You hear a kind of impenetrable texture, something like a very densely woven cobweb. I have retained melodic lines in the process of composition, they are governed by rules as strict as Palestrina's or those of the Flemish school, but the rules of this polyphony are worked out by me. The polyphonic structure does not actually come through, you cannot hear it; it remains hidden in a microscopic, under-water world, to us inaudible." Ligeti in Conversation: 14-15.

2 "It is perhaps my Second Quartet which reflects my ideas most clearly - where you would find all the different techniques I have used." Ligeti in Conversation: 13. 
attend a ceremony at the University of Hamburg on that very day. There Ligeti was to be awarded an honorary doctorate, in celebration of his many years of teaching composition at the music faculty of that university.

Armed with my tape recorder, I arrived at Ligeti's apartment the next afternoon, and spent an intensive hour-and-a-half with the composer. We began our conversation in English, but we soon changed to Hungarian, whereby Ligeti's communication became immediately enlivened.

Many of the observations made by Ligeti have appeared, differently expressed, in previous interviews. ${ }^{3}$ However, his discussion with me of many details of his Second String Quartet (1968) is without precedent, and his accounts of the recent recording of his opera, Le grand macabre (1974-77), and of the influence of African music on his more recent writing were unusually detailed and informative.

S.S.

Satory: Mr. Ligeti, I should like to ask you mainly about your Second String Quartet; but I have some questions about your current compositional activity as well.

Your First String Quartet of 1954 is a motivically unified work, with harmonic and rhythmic elements which rely on Bartók as model. However, your Second String Quartet (1968) is not a motivic-thematic composition. It is clear, nevertheless, that there are underlying sub-motivic elements, the harmonic series and the chromatic scale for example, which provide unity within the movements, but also among the movements. Is it correct to go so far as to say that these constitute the underlying principle of this work, as Paul Griffiths wrote in his book on your music? ${ }^{4}$

Ligeti: I think so. My answer is yes.

S. Then, are the chromatic scale and the harmonic series among the "secret

3 See the chronologically arranged, selective listing of interviews with Ligeti, at the end of this article.

4 "In the Second Quartet, ... the unification seems to take place at a level beyond the thematic. The basic 'idea' constant throughout the five movements is perhaps no more than the chromatic scale, which is also a prominent feature of the First (Quartet). Or perhaps the underlying principle is, rather, the interpenetration of the chromatic scale with the pure intervals of the harmonic series, particularly the octave and the fifth." Griffiths 1983: 67. 
correspondences" or rhymes among movements to which you yourself have referred ${ }^{5}$

L. Well, chromaticism is present in the whole piece. But there is not a great number of chords which are related to the harmonic series; that is, they are present to a lesser extent. There are a great many things in that piece. Concerning chromaticism, there is an even distribution of the twelve notes, but without twelve-note rows. In addition, rhymes exist among the movements: an example is the flageolet melody at the end of the first movement and its return in varied form at the end of the second movement. In fact, such rhyming is evident only between the first two movements. But every movement is the variation of a single thought. It is very difficult to articulate this verbally: for, while composing this piece, I was thinking musically.

S. Of course. In the same connection, is Gianmario Borio, in his article, "L'eredità bartókiana nel 'Secondo Quartetto' di Ligeti ..." correct in ascribing to your Second String Quartet the same principle of continual variation which can be applied to many of Bartók's mature works, and indeed, to the works of Schoenberg and his Viennese colleagues? ${ }^{6}$

L. This perpetual variation is indeed Schoenberg's idea, principally in the String Quartet in F Sharp Minor (Op. 10, 1907-08). And it is possible that Bartók, who knew that string quartet very well, was strongly influenced by this principle, the principle by which one exposes and develops thematic formations immediately.

This does apply to my Second String Quartet. But it does not apply completely because in fact there is no thematic-motivic material there, in the Beethovenian-Schoenbergian, or even in the Bartókian sense. There are textures and transformations of textures, gestures, motions, types of motion.

5 "Die 5 Sätze sind unterirdisch miteinander verbunden, es gibt geheime Korrespondenzen, fast Reime, zwischen Details innerhalb der Sätze, alle 5 Sätze sind sozusagen gleichzeitig anwesend ..." (The five movements are linked together subliminally; there are secret correspondences, almost rhymes among details within the movements. All five movements are present all at the same time, as it were...) From a letter of August 5-6, 1968, written by Ligeti to Ove Nordwall, published in Nordwall 1971: 96.

6 "Il principio della variazione continua viene accolto da Ligeti ed elevato a potenza infinita." (The principle of continuing variation is welcomed by Ligeti and raised to infinite power.) 'L'eredità bartókiana nel 'Secondo Quartetto' di Ligeti. Sul concetto di tradizione nella musica contemporanea”, Borio 1985: 161. 
There are transformations, but on other planes. But one may call it continual variation, if one wants. Therefore, I agree with Borio's article.

S. I have read that it took the LaSalle Quartet more than a year to learn your Second String Quartet, and that the difficulty had to do with the detailed prescription of the harmonics in the piece. ${ }^{7}$ Was this the only factor in their difficulty? In the same connection, could you comment on the clash between pure intervals and equal temperament in this piece?

L. At the time that I wrote the Second String Quartet, I was not so concerned about this issue. More recently, I have been very concerned with microtonal possibilities and also with pure intervals. I have investigated the music of non-European cultures, and equidistant or quasi-equidistant tonal systems.

But at the time of the Second String Quartet, I was not yet conscious of this. And yet I was occupied with microtonality when I wrote Ramifications in the following year (1969), in the year immediately after the writing of the Second String Quartet; however, Ramifications does not have quarter-tones. I'm sure you are familiar with this piece. There is no attempt here to produce exact quarter-tones, as in Hába's music. But it departs from twelve-note temperament by virtue of the fact that there is a discrepancy in tuning between the two groups.

I wrote the Second String Quartet and the Ten Pieces for Wind Quintet at approximately the same time (1968). Opposition between tempered chromaticism and pure or other intervals was not really part of my conception at that time. Nor did I think consciously about harmony at that time. A little later, in the Kammerkonzert at the end of the Sixties (1969-70), and also in Melodien at the beginning of the Seventies (1971), harmony became a principal consideration: then I did concentrate very intensely on harmonic thinking. In the Second String Quartet, there are chromatic pilings-up, even if these are not always clusters. There are various chord-formations which I sought completely intuitively, just like Bartók in his Second String Quartet, or like Stravinsky in Le Sacre. They are rather complementary harmonies, but within chromaticism.

7 “... the prevalence in the music of harmonics, and the resulting interference of pure intervals with their equivalents in the system of equal temperament. This requires exacting notation, and it was largely Ligeti's detailed prescription of harmonics that was responsible for the quartet's delayed première: the LaSalle Quartet, for whom it was written, needed more than a year in which to learn it." Griffiths 1983: 68. 
S. You have stated that the Second String Quartet sums up your various previous styles of composition. One such style is the so-called micropolyphonic one which appears in Atmosphères (1961), and in the "Kyrie" of the Requiem (1963-65). But in the "thinned-out micropolyphony" of the first movement of the Second Quartet, you avoided the canonic writing which you used in the micropolyphonic textures of previous works and managed to avoid writing canons or sequences. In fact, in the central section of this movement, aside from chromatic scales with octave displacements, sometimes presented in contrary motion, no clear melodic patterning is in evidence in much of the movement's polyphony. Could you explain your departure from your usual practice here?

L. First of all, I had only four instruments. I first employed micropolyphony in the orchestral piece, Apparitions (1958-59), which requires quite a large number of voices. The simplest occurrence of micropolyphony was in the Lux aeterna (1966), for a cappella chorus, in sixteen vocal parts. With the four instruments of a string quartet one may have more than four voices, with multiple stops.

In the Second String Quartet, I reduced the micropolyphony at once. I did this, not because I was writing a quartet, but rather the reverse. I had developed the technique of very, very dense polyphonic textures. With the Second String Quartet I strove to do something different. I did so by modifying this technique, without abandoning it altogether.

In reality there are no melodic or tuneful thoughts at all in the Second Quartet. In the last movement there appear motivic-melodic allusions of quite a primitive sort. But, along with the overall conception, with the types of motion, even with the mechanical types of motion in the pizzicato (third) movement, there are textures in the quartet, textures which tear away, textural unfoldings and textural dissolutions. It was thoughts such as these which occupied me then. My thinking of that time was completely musical. Today, however, I hold a completely different position in this regard. I am at a different point.

S. A remarkable feature of the second movement has to do with the gradual transitions in timbre, which are effected by means of pizzicato and tapping on the strings with either hand. Composition with timbres abounds elsewhere in the quartet. The first movement opens with a fascinating whistling polyphony effected by the tremolo playing of harmonics. And the subtle unison opening of the second movement has points of imitation marked by different modes of playing (and by the playing of the same notes on different strings): a different timbre in each case. 
L. What is involved here is a change of string in the production of the same pitch. A pitch sounds quite different when produced on the D-string instead of the G-string.

S. Of course. And yet your use of special string effects is not displayed for its own sake, but is integrated with other compositional procedures. How central were such considerations in your mind when you wrote this piece? And does the piece not refer back to your experiments in timbre composition in Atmosphères?

L. Yes, strongly. This is true especially in the second movement. There we have the colour-transformation of a single pitch, which remains in unison. I had written in this way a short time before, two years earlier, in ' 66 , in the Cello Concerto. There the music begins with $\mathrm{E}$ above middle $\mathrm{C}$, and that pitch is slowly "coloured over". This was my manner of working in the late 1960s.

S. The long chordal passage at the beginning of the quartet's fourth movement, "Presto furioso, brutale, tumultuoso", has a high level of harmonic dissonance. I have tried to see how you selected your pitches in this section, but I have not succeeded. Can you help me here?

L. I cannot tell you a great deal about that even today. I am sure that I knew what I was doing while I was writing it, but I would not know how to go about analyzing it. My thinking at that time was strongly chromatic. That was considerably changed later, in my Horn Trio (1982), with which you are probably familiar.

At the time of the Second String Quartet I strove to utilize the total chromatic selection of pitches all the time beginning with the system of twelve notes. With the chord sequences of the fourth movement, where each chord does not contain all twelve notes, but rather fewer notes, I strove for a certain complementarity, like Schoenberg and Berg. But I don't think that it is possible to analyze this piece in the same way that one analyzes a functional, tonal piece.

There are no connections among the chords. Rather, cumulative thinking is involved. There is very little that is rational here. Of course, during composition, intuitive and rational considerations are both present at some point. But they constantly correct each other. However, to determine this after the fact, to say where this happened and which notes are involved, is difficult. A great deal depends on string technique, on the notes that are possible to reach in multiple-stop playing.

S. Is there not a connection with Bartók's string quartet style in this movement, with the martellato bowing? 
L. Yes, Bartók is present in the entire Second String Quartet, indirectly. But this is most strongly the case with the middle movement, the pizzicato movement, which connects with the pizzicato movement of Bartók's Fourth Quartet (fourth movement). By the time that I wrote my Second String Quartet, I knew Bartók's Fourth String Quartet quite well.

S. You have mentioned in your interview with Josef Häusler in 1969 that there is a moment in the fifth movement which is particularly evocative of Bartók's music. ${ }^{8}$ I suspect that it is the very short outburst which is played triple forte, after a very long rapid passage in vertical octaves (m. 50); this passage has conjunct, "circular" melody, to borrow a term from Lendvai," harmonized by means of three minor seconds. Am I right in this assumption?

L. There is one such place. It is not a quotation but rather an allusion. In fact, I was thinking of the whole section. This whole section (mm. 41-50) is Bartókian, not only its last measure which you have mentioned.

S. The fifth movement is clearly the movement with an unequivocal return of its initial material, the $D \sharp-F \#$ dyad, at the end. Formal closure is certainly a practice that you have avoided over the years. But it may be fair to say that you have "enveloped" many of your movements and compositions by having "narrow" textural beginnings and endings. You have avoided even the fortissimo, Beethovenian endings adopted by Bartók in his First, Third, Fourth and Fifth Quartets. Does this "enveloping", if I may use the term, have for you a visual or literary counterpart, a synaesthetic significance?

L. I did not think about this. This is rather a matter of taste, a reaction against very typical coda-elements, which indicate the end of a piece. It is clearly a reaction also against the reprise ethic, against sonata and rondo form. In my later pieces, in my compositions of the Seventies, I no longer concerned myself about this. In these later pieces there are many clear reprises.

Optical associations like envelopes are constantly in front of me when I compose. I always think of spatial forms as units, visual or tangible units. From this standpoint my acoustical conception always has a synaesthetic side.

8 "I don't want to deny that I was greatly influenced by Bartók, particularly in my early days, and this (Second) String Quartet contains a quite intentional little homage to Bartók. His music is not quoted, but its aura is present within a context that is quite different." Ligeti in Conversation, 104.

9 "Duality and Synthesis in the Music of Béla Bartók", 52, 53, 60. 
I concern myself with colours, forms, continuities. And I always put them into a spatial model, like an object in space.

S. Have you read Ernő Lendvai's analysis of Bartók's music? He makes biological associations with Bartók's circular melodies. ${ }^{10}$

L. Yes, yes. One would have to ask Bartók to see whether this is borne out in his music. The growth of plants and animals and such considerations have occupied me very strongly, but rather more recently, in the Eighties.

And in my music, there are mathematical considerations, considerations of fractal geometry. Fractal geometry is mathematics and not art. But it is an area which became well known only in the mid-Seventies. Its kind of growth and its processes of pattern transformation have occupied me a great deal. Its kind of thinking, of growth, degeneration, decay and branching-out did exist for me at the time of the composition of the Second String Quartet. Indeed, Ramifications (1969), which I wrote right after the String Quartet, deals with branchings-out, and this is already in its title. But this sort of organic growth is more strongly present in the pieces of the Seventies. It is there in the Second String Quartet, but not consciously.

S. In the interview which you conducted with yourself in 1971, you stated that in the 1960's you became disillusioned with the harmonic and rhythmic neutrality of Atmosphères and the first two movements of the Requiem; you stated also that the abandonment of rhythmic neutrality was evinced especially in the Second String Quartet. ${ }^{11}$

L. I was no longer satisfied with harmonic and rhythmic neutrality. It is not the case, however, that I became opposed to it. I employed it in Atmosphères and in the Requiem, and in other pieces, for example in Volumina. And then I began to look for a new kind of harmonic system, and I am still looking for it today. I am searching for new rhythmic configurations as well.

10 See, for example, Béla Bartók, An Analysis of His Music, 29-34.

11 “. . . revulsion against my own use of neutral harmony and rhythm, on which (as a consequence of Apparitions) I built my pieces from Atmosphères up to the first two movements of the Requiem, led around 1964 to the abandonment of harmonic neutrality and to the construction of intervallic seed crystals - for example in the final movement of the Requiem and later, more clearly, in Lux aeterna and Lontano. It led also, after 1968, to the abandonment of rhythmic neutrality, most consistently in the Second String Quartet." Ligeti in Conversation, 125-6. This self-interview was originally published in German in Melos, 1971. 
S. Can your abandonment of rhythmic neutrality be construed to mean a new rhythmic inventiveness?

L. No, rhythm is not present as formation, as Gestalt, to use the German word, or as pattern. Rhythm was suppressed in Atmosphères and in the Kyrie. Now I do not wish to return to older, worn-out rhythmic formations.

Later, I began to look for new solutions in the realm of rhythmic structures. This was still very much in the seminal stage in the Second String Quartet. In it there are various "tearing" gestures.

S. You have mentioned in an article in Italian of 1985, "La mia posizione di compositore oggi" that your recent music has been influenced by the complex polymetric music for player piano of Conlon Nancarrow, and also the rhythmically complex musics of Caribbean Islands and of the Central African Republic. ${ }^{12}$ I have two questions about it: which Caribbean islands did you mean? And could you explain more specifically how these influences are introduced into your music, for example in the second movement of the Horn Trio?

L. Yes, I can speak quite accurately in this connection. For a great many years I have been very interested in asymmetrical rhythms, which Bartók called Bulgarian rhythms. They are actually not only Bulgarian but are characteristic of the whole Balkan Peninsula and also of Anatolia [Asiatic Turkey]. These asymmetrical rhythmic formations have been very much in line with my search for new rhythmic solutions.

Already in the Seventies I listened a great deal to commercial Latin American folk music. But, at that time, I did not know a great deal about African music. Certainly there were folklore recordings of African music, but I did not come across them. They were difficult to obtain at that time.

Then, in 1978, I wrote Hungarian Rock: already, the accompanying rhythm of this piece has an asymmetrical metre, in $9 / 8$ time. It has a little of the influence of Latin American rhythm. But it was derived from the commercial semi-folklore of South and Central America and from pop music and jazz. My acquaintance with Latin American music was limited to pop and jazz at that time.

In 1980 there arrived in my composition class in Hamburg a young Puerto Rican composer, Roberto Sierra. And through Sierra, who came from the

12 Ligeti 1985: 4. 
heart of Latin American culture, I got to know quite a lot of Caribbean music. And in 1980, through him I discovered a great deal of music which does not exist on recordings, at least not on commerical recordings. So, first of all, through Sierra, I got to know Puerto Rican recordings. And I heard a lot of Cuban music: tapes of émigré Cubans, and tapes which emanated directly from Cuba. I have found that the most interesting music is the music which is or was from Cuba itself.

Then, slowly, I began to hear more recordings; but now I heard recordings from Caribbean cultures which were completely different from the above, that is, from Jamaica. It is not only reggae which is popular in Jamaica, but there is also music that is connected with various cults, various syncretic Christian cults. And actually, the same is true of the entire black population of Latin American countries. In addition, I heard recordings from Haiti. And then I began to develop an interest in this entire region.

There is Caribbean influence in the second movement of my Horn Trio of '82. There it is coupled together with folk music not only from Bulgaria but from the Balkan Peninsula in general. Since I was born in Transylvania, I knew already a good deal of this music quite well, mainly Roumanian folk music. Already in my childhood I was acquainted with Roumanian folk music, and later I was occupied with it when I lived in Hungary. Nevertheless, I have been very interested in the entire Balkan area, and I am still interested in it today. These two musics, Caribbean and Balkan, are quite different. They have almost nothing to do with each other, except for their asymmetrical rhythmic constructions.

And then, the first African recording hit me like a bomb. I don't know if you are familiar with the UNESCO record series of Philips, one of which is entitled Banda Polyphonies, which was assembled by Simha Arom, an Israeli ethnomusicologist who works in Paris. I did not know him then, but since that time I have made his acquaintance and the acquaintance of other ethnomusicologists.

It was in the fall of ' 82 that I heard this recording. It was again the Puerto Rican composer who brought it along. And the Banda ... I don't know if you know the music of the Banda tribe; theirs is a very special kind of music. It had a very profound effect on me. This effect is not yet evident in the Horn Trio, because that was just before it. By the time that I heard this record, the Horn Trio had already been completed. Indeed, it had already been performed. But the music of Central Africa has an impact on what I began to compose afterward, in my Piano Études (1985).

There is a twenty-piece orchestra on this recording of the Banda. Simha Arom 
writes on the record jacket that it has trumpets, instruments made out of antelope horns and the trunks of trees. The high instruments are capable of producing two pitches, and the lower ones, only one pitch. But they play a very complicated polyphonic music, in twenty parts. It is pentatonic music, in multiple octaves, in four octaves. This is how it ends up in twenty parts. Every instrument has its own rhythmic pattern. The music is very reminiscent of the technique of Machaut and Philippe de Vitry, but it is much, much more complicated rhythmically. This kind of polyrhythm does not exist in the European musical tradition.

Complex musical cultures had already interested me for a long time before this. Already in the Seventies I heard a great deal of gamelan music from Bali. But I was even more gripped by this African music. Since I heard this, in the late fall of ' 82 , I have been in the throes of an African fever. I have never travelled in Africa. But I have tracked down many recordings, hundreds of them, the most interesting recordings in Paris.

And as far as my connection with African music is concerned, I have not used it in the manner that Bartók employed Hungarian or Roumanian or Arabic music. African music has not left traces in my pieces, but its rhythmic system has.

S. On quite a different topic, someone with whom I spoke yesterday mentioned that your Piano Concerto was premièred a month ago here in Hamburg.

L. They have already played the Piano Concerto several times in Europe, but the Hamburg première was indeed exactly a month ago.

S. And will it appear in publication through Schott?

L. Yes, it will be published. ${ }^{13}$

S. I have heard that the recording of Le grand macabre has also been completed.

L. It has been completed, but it has not yet been edited. The tapes are available, but the final version has not yet been decided upon because it was recorded at different times. It was recorded in concert form, but there were two big mistakes made at this concert. The end of one of the pieces became completely confused because the saxophone player forgot to come in. And the coloratura soprano who has a principal role became ill, without warning; so,

13 The Piano Concerto appears in the Schott publication catalogue of 1987, but its release has been delayed, for reasons unknown. 
there was no coloratura soprano. A trumpet player had to play the coloratura arias.

As a result, it was an improvised affair. The end of the piece will be edited in from the version of the dress rehearsal; this has not yet been done. And, in the meantime, they have managed to record the coloratura parts, but that also has to be edited in. So, there has not yet been a tape of the entire opera as a whole, but I hope that it will soon be recorded. Then there will be a recording published. ${ }^{14}$

S. You mentioned in an article to which I referred earlier ("La mia posizione di compositore oggi") that there are traces of Hungarian and Roumanian folk music in your recent works. It seems that for twenty five years or so, between the Bagatelles for Woodwind Quintet of 1953 and the harpsichord pieces of 1978, Hungarian Rock and Passacaglia ungherese, you avoided incorporating elements of Hungarian and Roumanian folk music into your compositions. But is it not true that in these harpsichord pieces, then in the Horn Trio and in the Hungarian Études for a cappella chorus (1983), you have returned to your roots, so to speak, and allowed yourself to express nostalgic feelings?

L. Without a doubt. There were certain limitations in the harpsichord pieces; they are rather ironic footnotes. But what you say is true, without a doubt, of the Horn Trio and of the Hungarian Études.

S. Could you possibly elucidate how you have been affected in your composing by the type of thinking involved in computer science, and perhaps indicate how that has manifested itself in your recent compositions?

L. I have not been interested in computers as machines, but rather by the whole mode of computer thinking, that of thinking on several levels. Such thoughts have occupied me in composition; that is, thoughts in various levels of abstraction.

Because of this, I have also been concerned with acoustical illusions, especially in my more recent pieces, the Piano Études and the Piano Concerto. In these compositions, we hear melodies which have not been played, which are created out of the interaction of different instruments. Or, a single performer, the pianist, might play in several tempos at the same time. In reality, he plays in one tempo, but creates an acoustical illusion. These thoughts are organized

14 The phonograph recording, "Scenes and Interludes from Le grand macabre" has been released on Wergo 60085 . 
in such patterns and complexities. These would not have come into existence if I had not been acquainted with computer science.

I have not worked with computers. I do not even have a little pocket calculator. But I have been concerned a great deal with the whole world of thought which surrounds computer science and artificial intelligence. And this also had quite a concrete initial impulse, just like the African record which that Puerto Rican student of mine brought.

This whole environment, this computer science environment, had a very great effect on me, all the more so because I had been very interested in all of this previously, in this entire branch of thinking. But I am not interested in this branch of thinking technically. I am amateur in computer science; I am neither a physicist nor a computer scientist. Rather, I have read a great deal of the published literature of computer science, in Scientific American, in its German edition. I have gleaned a great deal of information from that journal.

I have read two books by Douglas Hofstadter, which you probably know. They are quite essential for a musician. One is Goedel, Escher, Bach. Goedel was the mathematician, Escher was the graphics artist and Bach, Johann Sebastian. And a collection of Hofstadter's articles has appeared with the title, Metamagical Themas. This is actually higher-level journalism. The reading of such books is very conducive to thought.

And then I began to be progressively more interested in the scientific realm. There was the new mathematics, fractal mathematics, but also a great deal more, the self-organization of genetic formations. Thoughts about science have occupied me a great deal, and I have read a great deal about them. I have read not only journalism and let's say, popular books, but also scientific books, mainly about mathematics. These have related back very powerfully to my compositional thinking. I have read these books because in my compositions I was dealing with similar concepts, especially with complexity and pattern. Actually, I had already begun to think this way with Atmosphères and micropolyphony. So, this is how my compositional thinking has changed gradually.

S. Do you think that your music has had an impact on the development of contemporary Hungarian music?

L. I have no idea. I don't think so. I have seen strong influences on Hungarian composers from the work of the minimalists, that is, of Terry Riley and Steve Reich. There is a very important direction of this kind among young Hungarian composers, in the direction of American minimalism. And I know 
that Stockhausen has made a strong impression. But I do not think that my music has had much of an influence.

S. It has come up in the course of my conversations with Hungarian composers, however, that they have indeed been influenced by your work, especially your famous micropolyphonic style.

L. There was a parallel phenomenon in Polish music, with Lutoslawski, Penderecki, Serocki and others, at about the same time, since 1960. Therefore, I have had the impression that the music which was oriented in the direction of sonic discoveries and sonorities and which dominated in Hungary during the Sixties and Seventies is connected rather with Polish technique.

My thinking has been very different, even if at that time, around 1960, they grouped me together with Penderecki. I think, though, that mine is a completely different musical conception.

S. Several Hungarian composers have maintained that there is a recognizable Hungarianness in every Hungarian musical composition. This is, of course, simply not true. However, have Hungarian composers succeeded, in your view, in their quest for a new Hungarian voice in contemporary music?

L. Well, Bartók succeeded. I think that what there is in common, fundamentally, is the language, the spoken language, the Hungarian mother tongue. Composers have used certain accentuations, certain distributions of stress, certain metrical and rhythmic formations of the Hungarian language. The mother tongue has had a great influence on musical conceptions.

If Liszt had spoken Hungarian, he would have written music that was different. He tried very hard to write Hungarian music, but did not quite succeed. It was really Bartók who managed to do this at the very highest level. But, it is very difficult for me to make any kind of comment about this, about the question of belonging to a certain nationality, the question of belonging to a culture, and in general, the question of modernism. I find it difficult to comment because I am involved in these issues.

S. Thank you, very much, Mr. Ligeti, for this pleasant and informative conversation.

\section{List of Interviews with Ligeti}

The following is a selective and by no means exhaustive list of interviews with Ligeti, arranged in chronological order. Included are Ligeti's "selfinterviews" and writings about his own music. Annotations are provided in 
square brackets, indicating the works discussed. The dates given are dates of publication rather than dates on which interviews were conducted.

Häusler, Josef, "Interview mit György Ligeti," Melos 37 (1970), 496-507; revised version in Nordvall, Ove. G. Ligeti, eine Monographie (Mainz: Schott, 1971), 114-138; translation into French of the revised version in Musique en jeu 15 (Sept 1974), 110-124; translation into English of the revised version in Ligeti in Conversation, 83-102. [Ligeti discusses Lontano, Atmosphères, Apparitions, and Volumina.]

Häusler, Josef, "Wenn man heute ein Streichquartett schreibt," Neue Zeitschrift für Musik 131 (July-August 1970), 378-381. Reprinted in Nordvall, Ove. G. Ligeti, eine Monographie, 139-148; translation into English in Ligeti in Conversation, 102-110. [Provides information concerning the overall formal construction of String Quartet No. 2, and the character of its five movements.]

Ligeti, György, "Fragen und Antworten von mir selbst," Melos 38 (December 1971), 509-516. Translated into English by Geoffrey Skelton in Ligeti in Conversation, 124-137. [Ligeti makes a clear, cogent statement of his compositional principles and clarifies his relationship to twelve-note composition and to total serialism.]

Ligeti in Conversation (London: Eulenburg, 1983). Contains four interviews with Ligeti by three interviewers, and a Ligeti "self-interview":

1. Interview with Péter Várnai (pp. 13-83). [A translation of an interview in Hungarian, Beszélgetések Ligeti Györggyel (Conversations with György Ligeti) (Budapest: Zenemükiadó, 1979); translated into English by Gabor J. Schabert. The longest of all interviews with Ligeti; it has discussions of many works, including String Quartet No. 2, Atmosphères, Aventures, Requiem, Lontano, Continuum, Chamber Concerto, San Francisco Polyphony, and Le grand macabre.]

2. Interview with Josef Häusler (pp. 84-102). See Häusler, "Interview mit György Ligeti”.

3. Interview with Häusler (pp. 103-110). See Häusler, "Wenn man heute ein Streichquartett schreibt".

4. Interview with Claude Samuel (pp. 111-123). [Translation into English by Terence Kilmartin of an interview in French first published as Entretien avec György Ligeti (Paris: Hubschmid \& Bouret, 1981). Presents Ligeti's perceptions of Le grand macabre.] 
5. Ligeti self-interview (pp. 124-137). See Ligeti, "Fragen und Antworten von mir selbst".

Stürzbecher, Ursula, Werkstattgespräche mit Komponisten (Cologne: Gerig, 1971), 32-45. [A short, general interview.]

Christensen, Louis, "Conversation with Ligeti at Stanford," Numus-West 2 (1972), 17-20. [Focuses on Ligeti's perceptions of Stanford University and of California during his four-month sojourn at Stanford in 1972.]

Lichtenfeld, Monika, "György Ligeti gibt Auskunft," Musica 26/1 (1972), 48-50. [A brief interview, with fairly detailed references to Melodien.]

Jack, Adrian, "Ligeti Talks to Adrian Jack," Music and Musicians 22 (July 1974), 24-30. [Ligeti discusses Melodien in detail.]

Gottwald, Clytus, "Tendenzen der neuen Musik in den USA," Melos/Neue Zeitschrift für Musik 1 (1975), 266-272; also in Musik und Bildung 8 (February 1976), 57-61. [Ligeti discusses the music of American composers, particularly of minimalists Riley and Reich.]

Sabbe, Herman, "György Ligeti: Allusions et illusions," Interface 8 (1979), 11-34. [A substantial interview concerning Le grand macabre.]

Bouliane, Denys, "Entretien avec György Ligeti," Sonances - Revue musicale québecoise 3/1 (1983), 9-27. Translated into German as "György Ligeti im Gespräch," Neuland 5 (1984-85), 72-90. [Discusses Magyar Etüdök (Hungarian Études), Horn Trio and Le grand macabre.]

Griffiths, Paul, "Interview with the Composer," György Ligeti (London: Robson, 1983), 13-26. [Concerned exclusively with events of Ligeti's life up to 1961.]

Borio, Gianmario, “A colloquio con György Ligeti," Musica/Realtà 13 (1984), 5-9. [A short, general interview.]

Lichtenfeld, Monika, "Conversation avec György Ligeti," Contrechamps 3 (1984), 44-49. Translation from German by Daniel Haefliger. [Ligeti discusses his Horn Trio, Magyar Etüdök and Drei (Hölderlin) Phantasien.]

Szigeti, István, “A Budapest Conversation with György Ligeti,” New Hungarian Quarterly 25 (1984), 205-210. [A brief account of Ligeti's early years and of his Horn Trio.]

Wiesmann, Sigrid, "The Island is Full of Noise," Oesterreichische Musik 
Zeitung 39 (October 1984) 510-514. [Deals with the writing of the libretto of Ligeti's opera-in-preparation, The Tempest.]

Ligeti, György, "La mia posizione di compositore d'oggi," Ligeti, ed. Enzo Rostagno (Torino: Edizione di Torino, 1985), 3-5. [Ligeti writes about his music in a general manner, bringing the reader up to date on his work.]

Michel, Pierre, Interview with Ligeti in György Ligeti, compositeur d'aujourd'hui (Paris: Minerve, 1985), 127-182. [A long interview, with an extensive account of Ligeti's career, and detailed comments on many of Ligeti's works, for example Apparitions, Atmosphères, Requiem, Lux aeterna, Lontano and Melodien.]

Ligeti, György, "Mes Études pour piano (premier livre) : polyrythmie et création," Analyse musicale 11 (April 1988), 44-45. [A brief discussion of the first volume of Ligeti's six studies for piano (1985). Only the first volume has as yet been published.]

\section{REFERENCES}

BORIO, GIANMARIO.

1985: "L'eredità Bartókiana nel 'Secondo Quartetto' di Ligeti. Sul concetto di tradizione nella musica contemporanea," in E. Restagno, ed. Ligeti. Torino: Edizione di Torino, pp. 149-167.

GRIFFITHS, PAUL.

1983: Ligeti. London: Robson Books.

LENDVAI, ERNÖ.

1971: Béla Bartók, an Analysis of His Music. London: Kahn \& Averill.

1976: "Duality and Synthesis in the Music of Béla Bartók," in T. Crow, ed. Bartók Studies. Detroit: Information Coordinators, pp. 37-62.

\section{LIGETI IN CONVERSATION}

1983: London: Eulenburg.

LIGETI, GYÖRGY.

1985: "La mia posizione di compositore d'oggi," in E. Restagno, ed. Ligeti. Torino: Edizione di Torino.

MICHEL, PIERRE.

1985: György Ligeti, compositeur d'aujourd'hui. Paris : Minerve.

NORDWALL, OVE.

1971: György Ligeti, eine Monographie. Mainz: Schott. 